Institute of

Public Finance
NEWSLETTER

AN OGGASIONAL PUBLIGATION OF THE INSTITUTE OF PUBLIG FINANGE

\title{
Much ado about nothing - three questions about immovable property taxation in Croatia ${ }^{1}$
}

\author{
MARINA KESNER-ŠKREB Institute of Public Finance
}

\section{It is falsely believed that immovable property is subject only to the so-called ownership tax, as other taxes should also be considered, such as the immovable property transfer tax, inheritance and gift tax, taxes on income from the rental and sale of immovable property. There are as many as five different types of tax currently levied on immovable prop- erty in Croatia.}

2. These five types of tax are mainly local taxes, producing relatively small revenues in Croatia: in 2010, immovable property tax revenues, raised by the counties, cities and municipalities accounted for as little as 905 million kuna (6.9\% of total local tax revenues, or $0.8 \%$ of total tax and social security contributions revenues in Croatia). However, even in EU27, these taxes account for the smallest share of total collected tax revenues, and produce six time less revenue than, e.g. VAT or personal income tax.

3. The immovable property ownership tax was widely applied in Croatia as early as the I980s, and was charged on residential buildings, business premises and vacation houses. However, it failed to produce the desired effects, due to: I) the unrealistic assessment of the tax base; 2) incomplete property records; and 3) weaknesses in the work of the Tax Administration. Maybe the last century's experience will come in handy for us today.

The idea of introducing the immovable property ownership tax has again sparked off a stormy debate in Croatia. Therefore, this paper seeks to answer three questions concerning the immovable property taxation in Croatia:

I This paper is a follow-up to the analysis published by the author in 2009 (Kesner-Škreb, 2009). Therefore, the findings of that analysis will not be repeated here.
I. What taxes are levied on immovable property?

2. How much revenue do the immovable property taxes produce?

3. Has a comprehensive tax on immovable property ownership already existed in Croatia?

These are only some of the numerous questions, the answers to which should help in deciding whether it is even worth going on such an adventure as extending the immovable property ownership tax from vacation houses (currently the only kind of immovable property subject to taxation) to almost all kinds of immovable property. As shown below, from an administrative and a technical point of view, this is an extremely sophisticated and expensive tax, producing relatively modest budget revenues, and is therefore going to result in "much ado about nothing" (a quote from Shakespeare).

\section{WHAT TAXES ARE LEVIED ON IMMOVABLE PROPERTY?}

The immovable property taxation normally implies only the immovable property ownership tax. However, it should be borne in mind that immovable property is also subject to other taxes, which are seldom taken into account when analysing the overall tax burden on immovable property. Immovable property may thus be subject to three types of tax: the aforementioned immovable property ownership tax, immovable property transfer tax and tax on income derived from immovable property. The theoretical explanation of these taxes is given below.

(I) Immovable property ownership tax is collected on a regular basis, mostly annually and is based on the ownership of immovable property, usually buildings and land. 
It mainly constitutes the budget revenues of local government units, which fix the rates at which such property is taxed on an annual basis. The tax base is normally the value of the immovable property, assessed by the tax authorities according to various criteria (the market value of the immovable property, its location, size, quality, etc.). The taxable person is the immovable property owner. Many countries provide for exemptions from this tax, notably for apartments occupied by their owners.

(2) Immovable property transfer tax. Immovable property transfers include all cases in which a piece of immovable property changes its owner, i.e. when it is sold, purchased, exchanged, inherited or received as a gift. The revenues derived from this tax belong to the central government or local government units, which fix the tax rates. The tax base is the market value specified in a purchase contract, a contract of gift, or a deed of inheritance.

(3) Tax on income from immovable property. Immovable property can be used commercially and can produce income for its owner (from rental or sale). The tax on income from immovable property rental is paid by the lessor on the amount of the rental fee, which is usually reduced by actual costs (depreciation, repair, maintenance and interest), or lump-sum costs. The tax on income from the sale of immovable property is charged on the difference between the sale and purchase prices, i.e. on capital gains from the immovable property, accumulated from the moment of sale to the moment of purchase, as a result of price increases in the real estate market. The tax is paid according to one of the following two models: (a) as a part of the total income at the usual personal income tax rates, or (b) at special withholding tax rates, which normally differ form the personal income tax rates.

All the aforementioned taxes are implemented in Croatia under different names, in particular:

(I) Vacation house tax is a recurrent tax on immovable property, i.e. a tax on immovable property ownership, charged only on vacation houses. The ownership of other immovable property is not subject to taxation. According to the Act on the Financing of Units of Local and Regional Self-government ${ }^{2}$, the vacation house tax constitutes the revenues of cities and municipalities in the territory of which the vacation house concerned is located. It is paid annually by house owners at a rate between 5 and I5 kuna per square metre, which is determined by each city or municipality. It is a local tax, paid into the budgets of cities and municipalities. The vacation house owners are obliged to submit to the Tax Administration the informa-

2 NN II7/93, 69/97, 33/OO, 73/OO, I27/OO, 59/OI, IO7/OI, II7/OI, I5O/O2, I47/O3 I32/O6 and 73/o8. tion on their vacation houses, including their floor spaces. According to estimations, I3\% of households own vacation houses, meaning that there are about 200,000 vacation houses in Croatia (GfK, 2OII).

(2) Immovable property transfer tax is charged on the change of ownership of immovable property (through its inheritance, donation, purchase/sale, exchange, etc.).

- The immovable property transfer tax in the case of inheritance or donation ${ }^{3}$ is paid by the recipient at a rate of $5 \%$ on the market value of the immovable property. Exempt from the tax are the spouses, biological and adopted children, and, under certain conditions, brothers and sisters, etc.

- The immovable property transfer tax in the case of a purchase/sale (and other transfer) 4 in Croatia is paid by the purchaser at a rate of $5 \%$, on the market value at the moment of occurrence of the tax liability. This tax includes various kinds of relief, e.g. relief on primary dwelling or living in the areas of special state concern, etc.

Cities and municipalities are entitled to $60 \%$ and the central government is entitled to $40 \%$ of the immovable property tax revenues.

(3) Tax on income from immovable property is levied in Croatia as the tax on income from immovable property rental and tax on income from the sale of immovable property.

- The tax on income from immovable property rental is paid by the lessor at a rate of $12 \%$ on the rental fee, reduced by $30 \%$ on account of costs. The tax is paid according to a Tax Administration's decision in monthly amounts. Such income is not subject to filing a tax return.

- The tax on income from the sale of immovable property is payable by the seller, if the property is sold within three years from its purchase (after that the tax is no more payable). The tax at a rate of $25 \%$ is charged on the difference between the sales price and the purchase price, reduced by the sales costs. It is paid as wihholding tax and is not subject to filing a tax return.

3 The inheritance, donation and purchase/sale of immovable property are governed by the Zakon o porezu na promet nekretnina (NN 69/97, 26/Oo, 153/O2 and 22/II).

4 According to the Zakon o porezu na promet nekretnina; it is worth noting, however, that "new" immovable property, i.e. the property constructed, delivered or paid after I January 1998 is subject to value added tax. As the data on the VAT collected from the "new immovable property" are not available, this tax will not be further discussed in this analysis.

5 According to the Zakon o porezu na dohodak (NN I77/O4, 73/O8, $8 \mathrm{O} / \mathrm{IO}$ and II4/II) 
Table I.

Immovable property taxes in Croatia

\begin{tabular}{|c|c|c|c|c|c|}
\hline $\begin{array}{l}\text { Type of immovable } \\
\text { property tax }\end{array}$ & $\begin{array}{c}\text { Name of tax in the relevant } \\
\text { tax regulation }\end{array}$ & Tax base & Rate & Taxable person & $\begin{array}{c}\text { The tax } \\
\text { belongs to }\end{array}$ \\
\hline $\begin{array}{l}\text { Immovable property } \\
\text { ownership tax }\end{array}$ & Vacation house tax & $\begin{array}{l}\text { Floor space of the } \\
\text { vacation house }\end{array}$ & $\begin{array}{l}\text { 5-I5 kuna } \\
\text { per m } \mathrm{m}^{2}\end{array}$ & $\begin{array}{l}\text { Vacation house } \\
\text { owner }\end{array}$ & $\begin{array}{l}\text { Cities and } \\
\text { municipalities }\end{array}$ \\
\hline $\begin{array}{l}\text { Inheritance and } \\
\text { gift tax }\end{array}$ & $\begin{array}{l}\text { Immovable property transfer } \\
\text { tax in the case of inheritance } \\
\text { or donation }\end{array}$ & $\begin{array}{l}\text { Market value of the } \\
\text { immovable property } \\
\text { at the time of aqusition }\end{array}$ & $5 \%$ & $\begin{array}{l}\text { A legal or a natural } \\
\text { person inheriting } \\
\text { the immovable } \\
\text { property or } \\
\text { receiving it as a gift }\end{array}$ & \multirow{2}{*}{$\begin{array}{l}\text { Municipalities } \\
\text { and cities (6o\%) } \\
\text { and the central } \\
\text { government } \\
(40 \%)\end{array}$} \\
\hline $\begin{array}{l}\text { Immovable property } \\
\text { transfer tax }\end{array}$ & $\begin{array}{l}\text { Transfer tax in the case of the } \\
\text { purchase/sale of immovable } \\
\text { property }\end{array}$ & $\begin{array}{l}\text { Market value of the } \\
\text { immovable property at the } \\
\text { moment of purchase/sale }\end{array}$ & $5 \%$ & Purchaser & \\
\hline \multirow[b]{2}{*}{$\begin{array}{l}\text { Tax on income from } \\
\text { immovable property }\end{array}$} & $\begin{array}{l}\text { Tax on income from immovable } \\
\text { property rental }\end{array}$ & $\begin{array}{l}\text { The rental fee reduced by } \\
30 \% \text { on account of costs }\end{array}$ & $\mathrm{I} 2 \%$ & Lessor & \multirow{2}{*}{$\begin{array}{l}\text { Government, } \\
\text { municipalities, } \\
\text { cities and } \\
\text { counties }\end{array}$} \\
\hline & $\begin{array}{l}\text { Tax on income from the sale } \\
\text { of immovable property }\end{array}$ & $\begin{array}{l}\text { Receipts from the sale, } \\
\text { minus purchase price, } \\
\text { minus sales costs }\end{array}$ & $25 \%$ & Seller & \\
\hline
\end{tabular}

The aforementioned taxes constitute the personal income tax, which is a joint tax, i.e. it is shared among the government, municipalities, cities and counties according to special rules.

Accordingly, immovable property in Croatia is already subject to five types of tax: vacation house tax, tax on income from immovable property rental, tax on income from the sale of immovable property, transfer tax in the case of inheritance or donation and transfer tax in the case of the purchase/sale of immovable property. Therefore, the analysis of the tax burden on immovable property should take into account the total burden of all the five types of tax, rather than be focused, as usual, on the ownership tax only. An overview of the main technical characteristics of these taxes is given in Table I.

It should be borne in mind that immovable property is also subject to the payment of utility fees that are not typical taxes but are considered as non-tax revenues. The utility fees are paid by owners or users of residential property, business premises, garages, building land on which a business activity is carried out and undeveloped building land. The utility fees constitute the revenues of local government units, so that their amounts are determined by the municipalities and cities in the territory of which the immovable property is located. They are used for the financing of public infrastructure development and maintenance, as well as for education, health care and social welfare. This is why the utility fees, being nontax revenues, are very similar to the immovable property ownership tax, with the exception that they are not paid into the local budgets but to those of local utility companies. When considering the extension of the scope of immovable property ownership tax, account should also be taken of the burden the utility fees impose on immovable property, as the funds thus collected are considerable. In 2OIO, cities and municipalities collected utility fees worth 2 bn kuna, double the amount of all the five immovable property taxes, which accounted for as little as 905 million kuna (Table 2) (Klemenčić, 2009; IJF, 2OII).

Table 2.

Local immovable property taxes, 2002 and 2010

Tax amounts (in million kuna)

\begin{tabular}{|c|c|c|c|c|}
\hline & & & into & $b(70)$ \\
\hline & 2002 & 2010 & 2002 & 2010 \\
\hline Total local taxes & $6,927.3$ & I3,2OI.5 & & \\
\hline Total immovable property taxes & 565.6 & 905.2 & 8.2 & 6.9 \\
\hline $\begin{array}{l}\text { Tax on income from the rental and sale } \\
\text { of immovable property }\end{array}$ & 43.8 & I24.O & 0.6 & 0.9 \\
\hline Vacation house tax & IOO.O & I33.2 & I.4 & I.O \\
\hline $\begin{array}{l}\text { Tax on Immovable property transfer (including } \\
\text { purchase/sale, inheritance and donation) }\end{array}$ & $42 \mathrm{I} .8$ & 648.0 & 6.1 & 4.9 \\
\hline
\end{tabular}

Source: Ministry of Finance of the RC; non-consolidated data for all counties, cities and municipalities. 


\section{HOW MUGH REVENUE DO IMMOVABLE PROPERTY TAXES PRODUGE?}

As shown in Table I, the immovable property taxes mainly constitute the revenues of the cities and municipalities in the territory of which such property is located. Table 2 and Graph I below show total immovable property taxes, i.e. the taxes on income from the rental and sale of immovable property, vacation house tax and immovable property transfer tax (including data on the taxes on the purchase, donation and inheritance of immovable property), representing the local government units' budget revenues.

Of a total of 13 bn kuna in local taxes collected in 20IO, immovable property taxes accounted for 905 million kuna or $6.9 \%$ (only $0.8 \%$ of total tax revenues collected in Croatia) (Ministry of Finance of the RC, 2OII). The largest amount, about three fourths of the total immovable property tax revenues, came from immovable property transfer taxes, i.e. mainly the taxes on the purchase/sale, inheritance and donation of immovable property. The vacation house tax produced as little as I33 million kuna in
As immovable property taxes mainly constitute the local budget revenues, it is interesting to analyse their movements across the counties. As shown in Graph I, aboveaverage revenues from immovable property taxes in 2002 and 20Io, were mainly reported by the same counties, i.e. County of Istria, County of Zadar, County of Šibenik-Knin, County of Primorje-Gorski Kotar, County of Sjplit-Dalmatia, the County of Dubrovnik-Neretva and County of Lika-Senj. The revenues from immovable property taxes collected by these counties in 2010 accounted for $7 \%$ to $17 \%$ of their total tax revenues. However, 2OIO saw a fall in collected immovable property taxes relative to 2002, with the exception of the County of Istria, which even increased its collection rate by one percentage point from 2002. At the opposite end of the spectrum were County of Sisak-Moslavina, County of Virovitica-Podravina and County of Požega-Slavonski Brod, with the lowest average revenues from immovable property taxes, barely $5 \%$ of total local tax revenues in 2002 and even half as much (2\%) in 2010.

Hence, the revenues collected from immovable property taxes are very low. However, the situation is not much

\section{Graph I.}

Shares of total immovable property taxes in total local taxes per county, 2002 and 2010

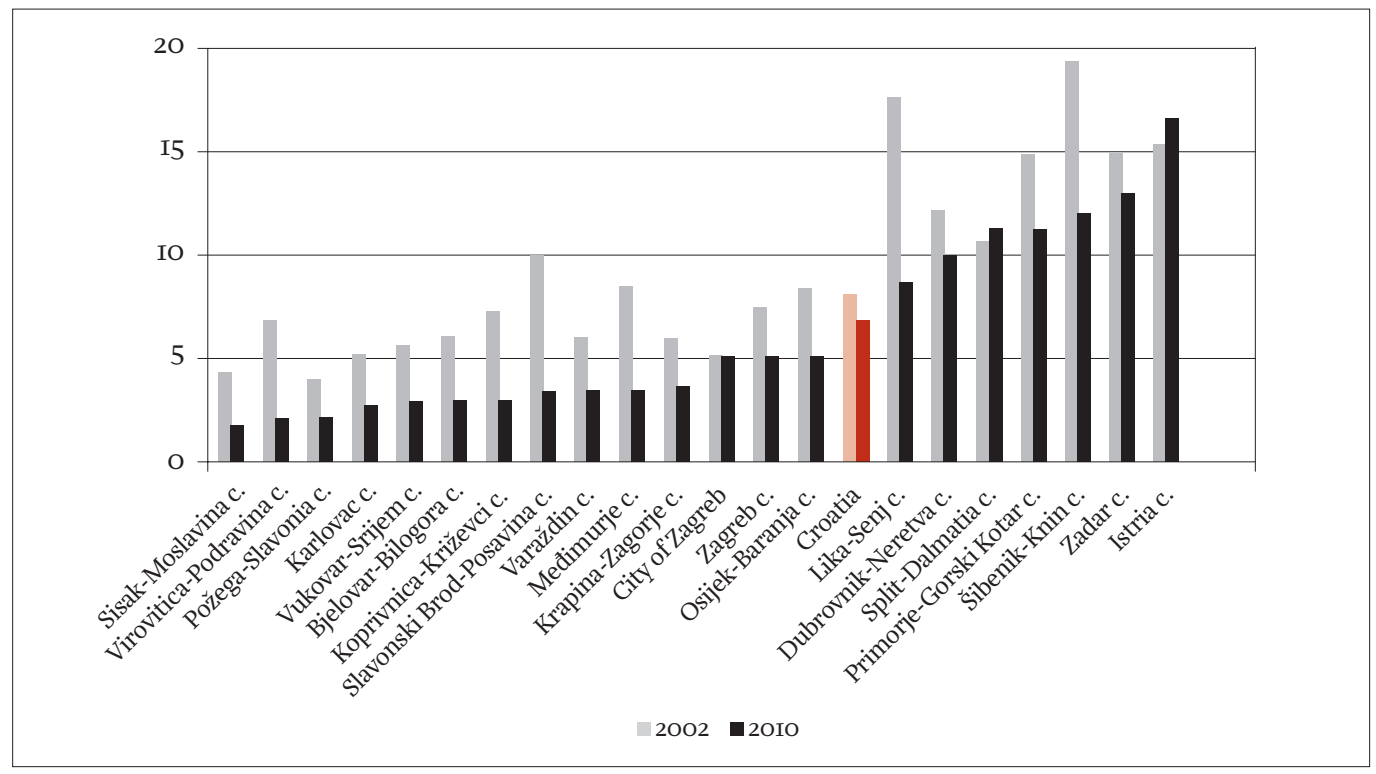

Source: Ministry of Finance of the RC; non-consolidated data for all counties, cities and municipalities.

local budget revenues in 20IO, or I\% of total local tax revenues, down o.4 percentage points from 2002. The contribution of income taxes on the rental and sale of immovable property to local budgets was also negligible (o.6\% and $0.9 \%$ in 2002 and 2010 respectively). better in EU27 either (see Graph 2). Property taxes ${ }^{6}$ are the least significant in the group of major taxes, having produced six time less revenues in 2009 than, for example VAT or personal income tax.

6 Mainly the immovable property taxes. 


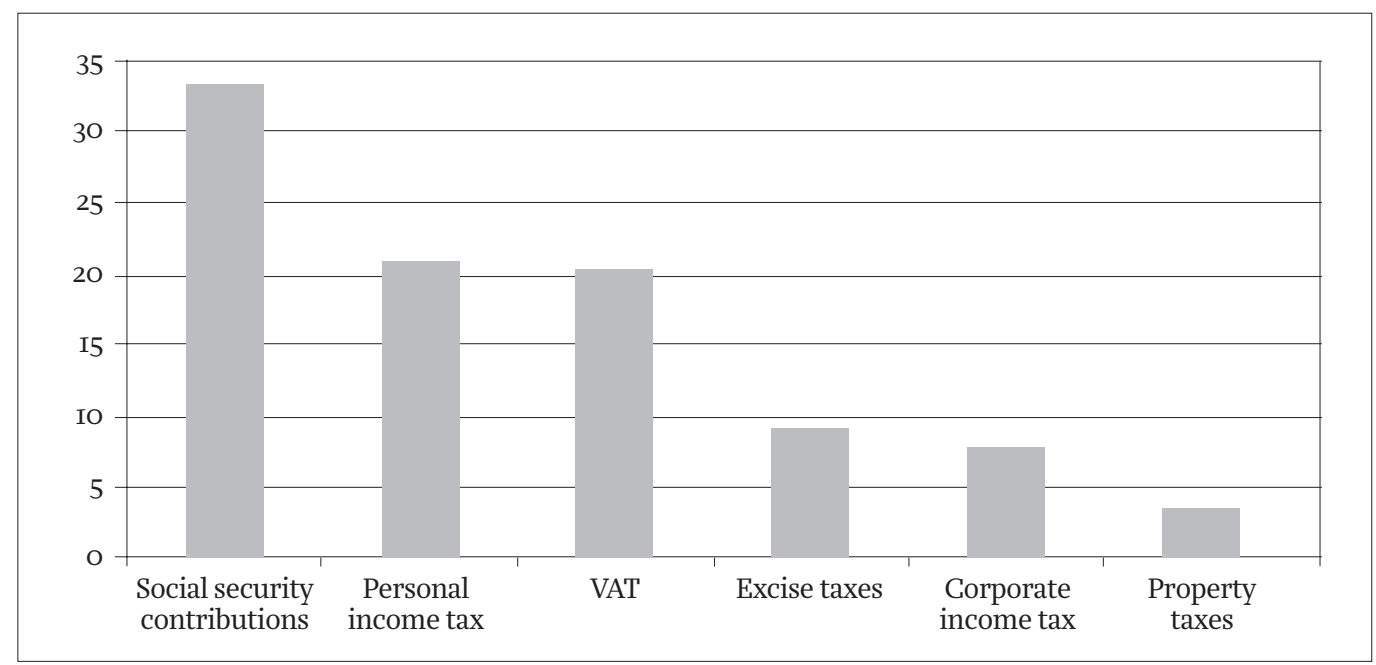

Source: IMF (2OII)

\section{HAS A GOMPREHENSIVE IMMOVABLE PROPERTY TAX ALREADY EXISTED IN GROATIA?}

Vacation house tax is the only immovable property ownership tax currently applied in Croatia. It should be noted, however, that a much more comprehensive immovable property tax was applied in Croatia (i.e. former Yugoslavia) during the 1980 , the so-called property tax, which was charged on residential buildings, business premises and vacation houses. While this tax was applied in a completely different economic and fiscal environment, one should recall, based on a paper by Professor Šimović, the theoretical dilemmas and practical problems involved in this tax.? Even though the tax was applied some thirty years ago, we are nowadays confronted with similar dilemmas. Therefore, it is useful to learn something about the difficulties facing tax officials at that time, in order to avoid repeating their mistakes.

Some general principles that used to concern tax experts during the I980s are still relevant today. One of them is that the immovable property ownership tax should not affect the substance of immovable property, i.e. that the tax may not be paid from the value of the property. This implies that the tax must only theoretically relate to the immovable property, but in reality, it should always be paid from the taxpayer's income. Therefore, the immovable property taxation must always be interdependent with income taxation. Any tax that would affect the substance of some property would result in a spillover of the property from the private to the public sphere, with a series of adverse economic and social consequences.
Then it should be determined which private immovable property should be taxed: the entire immovable property or only surplus property, i.e. the immovable property above a certain value. If the goal is to tax the ownership of the above-average value of immovable property, then the average value of the property should be assessed, which will be tax-exempt. This should primarily include the immovable property occupied by its owners or their immediate family members. Should this principle be followed, then an inventory of all immovable property should be made, and it should be clearly determined which of them are occupied by the owners or their immediate family members.

The idea to introduce a tax on unused property has recently been brought up again, while it is forgotten that taxes on uncultivated agricultural land, undeveloped building land and unused entrepreneurial real estate had already been applied in Croatia (from 200I), but were lifted in 2007, pursuant to a Constitutional Court decision ${ }^{8}$, as being unconstitutional, i.e. contrary to the constitutional principles of equity and fairness of the tax system. Moreover, they were not only declared unconstitutional, but their financial effects were very modest. Thus, in 2006, i.e. a year before their abolishment, the total revenues produced by these taxes in all the municipalities which applied them amounted to as little as 6.6 million kuna ( $2 \%$ of own municipal revenues, or $\% \%$ of total tax and social security contribution revenues of the government (Ministry of Finance of RC, 2007:229). 
Below are the technical characteristics of the immovable property ownership tax, applied in former Yugoslavia thirty years ago, showing the manner of determining the taxable persons, tax base and tax rates. Perhaps they can offer some guidance for tax officials today, and help them create a reasonable, fair, cost- effective and administratively practicable tax on immovable property ownership.

Taxable persons subject to property tax under that system were the owners of residential buildings or apartments, business premises, vacation houses or apartments and garages. However, owing to various benefits and exemptions, no tax was paid on apartments or residential buildings, occupied by their owners or their immediate family members, buildings and other facilities declared as cultural monuments and outbuildings owned by farmers. In addition, tax benefits were provided for all property used by its owners for business purposes.

If we would develop a simular model of immovable property ownership taxation in Croatia, which would exempt from tax the apartments occupied by their owners (according to the 200I Census, $83 \%$ of apartments were occupied by the owners, only Io\% were rented and $7 \%$ were shared with other families, (DZS, 200I)), and which would exempt cultural monuments, buildings used by farmers and craftsmen for the performance of their business activities, the tax base for immovable property taxation would be significantly narrowed. But of course, not all of the $83 \%$ the apartments occupied by the owners should be exempt from tax, regardless of their size. An option would be to determine the number of square meters per household member to be tax-exempt, but this would require a complicated procedure for determining the nontaxable floor space and counting the immediate family members living in such apartments. All this would open Pandora's Box of law circumvention through fictitious divorces, registration of subtenants as "immediate family members", etc. Charging tax on business premises would impose additional burden on enterprises, which should instead be disburdened and made more competitive.

The property tax base during the 1980 was the construction value of the immovable property, regularly adjusted for the price increases, and reduced by depreciation expenses and maintenance and management costs.

The application of such a tax base assessment model in Croatia would require the awareness of many problems connected with the value, revaluation and depreciation of immovable property.

The value of immovable property. A fair assessment of an immovable property tax requires an inventory of all immovable property, including the names of the owners and established values of the property items. The land registers contain the descriptions and locations of the immovable property, but not its value. Hence, the current market value, which is the tax base for the immovable property ownership tax, should be established for all immovable property items entered in the land register. Needless to say, a huge number of immovable property items are still not registered, and the OIB (personal identification number) has not yet taken hold, which is a serious impediment to a fair and comprehensive assessment of the immovable property tax base.

Revaluation. Once the initial value of immovable property is assessed, the immovable property should be revalued on an annual basis, in order to update its market value. This ensures that the tax is charged on the real value of immovable property, with the tax revenues following the movements in its market value. More specifically, due to changes in market supply and demand, the immovable property prices fluctuate, i.e. they go up in times of economic upswing and high inflation, but fall in years of recession and disinflation. Therefore, it is necessary to revalue immovable property on an annual basis. In view of this, the Tax Administration should have in place well elaborated models of annual immovable property revaluation, which still need to be developed. On the other hand, one should also recognise the maintenance and management costs, which reduce the tax base. This again calls for creating mechanisms for record keeping and control of such costs.

Also worth considering are housing loans, which burden the immovable property, sharply reducing the owners' income and financial solvency. According to CNB (2OII) data, In October 2OII, housing loans to households amounted to HRK 59bn (I7.6\% of GDP), while they were almost half as high in December 2006 (HRK 37bn or I2.7\% of GDP)). It follows that, for the assessment of the tax on immovable property ownership, banks should provide the Tax Administration with data on a huge number of loans and their users. This would, of course, be a time-consuming and expensive exercise.

Depreciation. During the I980s, the tax base was reduced by the annual depreciation expenses. According to the Croatian legislation, the depreciation period for buildings is 20 years, meaning that their value is decreased by $5 \%$ annually, which should also be taken into account for the tax base assessment.

Tax rates, applied in former Yugoslavia during the I980s on the above-defined tax base were progressive and differentiated according to the type of immovable property: 
- residential property: from o.I to I\%;

- business premises: from 0.I5 to I.25\%; and

-vacation houses: form 0.2 to $1.5 \%$.

The adoption of this model would raise the problem of delimitation among the immovable property items used for business, residential and vacation purposes. Such differentiation between tax rates according to the purpose of immovable property would require ongoing controls to avoid false registration of residence or a business activity.

All the above said, introducing a tax on immovable property ownership seems to be a, extremely demanding task for the Tax Administration. It would include the establishment of a series of databases and administrative procedures for the accurate assessment of the value of immovable property and, accordingly, for fair tax assessment. This means that all immovable property should be recorded in the land register. Then, the initial value should be determined for each immovable property item in the land register, and immovable property revaluation models should be developed. Moreover, a depreciation amount should be determined for each item, taking into account the investments made and housing loans taken by the owner, but also the immovable property maintenance costs, borne by the owner in a current year. It is also necessary to formulate the definitions of residential and business properties, as well as of a vacation house, on which different tax rates would be applied, and to set the tax-exempt minimum floor space per household, etc.

And finally, let us remember the warning by Professor Šimović, that the property tax from the I980s failed to achieve the set goals for a number of reasons: firstly, unrealistic tax base assessment; secondly, incomplete immovable property records; and thirdly, weaknesses in the work of the Tax Administration.

However, regardless of the time elapsed, today's problems seem to be similar. Therefore, it should be closely considered whether such an expensive and complicated tax, producing relatively small revenue to the budget, should at all be introduced.

\section{LITERATURE:}

GNB, 20II. Bulletin No. I76 [online]. Available from: [http://www.hnb.hr/publikac/bilten/arhiv/bilten176/ebilti76.pdf].

DZS, 200I. Popis stanouništva 200I. Zagreb: Državni zavod za statistiku.

GfK, 20II. “Trajna dobra u kućanstvima Hrvatske-20Io.” Orange Newsletter, (20) [online]. Available from: [http:// www.gfk.hr/imperia/md/content/gfkaustria2/pdf/ nlo_2O_final.pdf].

IJF, 20II. Registar neporeznih prihoda 2OII. Mimeo. Zagreb: Institut za javne financije.

IMF, 20II. GFS March [online]. Available from: [http://elibrary-data.imf.org/].

Kesner-škreb, M., 2009. What should one know about immovable property taxation in Croatia. Newsletter, No. 46 [online]. Available from: [http://www.ijf.hr/eng/ newsletter/46.pdf].

Klemenčić, I., 2009. "Komunalna naknada”. Porezni vjesnik, I8 (3), 65-67.

Ministry of Finance of RC, 2007. Annual Report of the Ministry of Finance for 2007 [online]. Zagreb: Ministary of finance. Available from: [http://www.mfin.hr/ad$\operatorname{minmax}$ /docs/GODISNJE_IZVJESCE_2007_ENG. pdf].

Ministry of Finance of RG, 20II. Vremenske serije - Konsolidirana opća država [online]. Available from: [http:// www.mfin.hr/hr/vremenske-serije-podataka].

Ministry of Finance of RC. Ostvarenje proračuna JLP $(R) S$ za period 2002 - 20IO. [online]. Available from: [http:// www.mfin.hr/hr/lokalni-proracun-2002].

Odluka Ustavnog suda Republike Hrvatske br. U-II559/200I. i U-I-2355/2002. od 2I. veljače 2007., NN 26/o7. Zagreb: Narodne novine.

Šimović, J., 1989. Porezni sistem i porezna politika općina u Jugoslaviji. Zagreb: Institut za javne financije.

Zakon o financiranju jedinica lokalne i područne (regionalne) samouprave, NN II7/93, 69/97, 33/OO, 73/oo, I27/OO, 59/OI, IO7/OI, II7/OI, I5O/O2, I47/O3, I32/O6, 73/o8. Zagreb: Narodne novine.

Zakon o porezu na dohodak, NN 177/O4, 73/o8, 80/ıo, II4/II. 